\title{
Změny sportovní výkonnosti ve vyšší nadmořské výšce \\ u běžců na lyžích
}

\section{Changes in sport performance of cross country skiers during high altitude training}

\author{
Jiří Suchý, Jan Pernica, Jakub Opočenský
}

Fakulta tělesné výchovy a sportu Univerzity Karlovy, Praha

\begin{abstract}
Abstrakt
Článek shrnuje výsledky výzkumu vlivu desetidenního pobytu a tréninku ve vyšši nadmořské výšce (1 $850 m$ n. m.) na změny sportovní výkonnosti u běžců na lyžich na úrovni aerobní, anaerobní a kritické intenzity zatižení prostřednictvím sledování srdeční frekvence (SF) a koncentrace laktátu v kapilární krvi. Pro ověrení byl využit nestandardizovaný běžecký terénní test (3x2km, interval aktivního odpočinku 10 minut). Zámérnè vybraný soubor běžcủ na lyžich $(n=7)$ absolvoval test celkem pětkrát: vstupní v nižině $(480 \mathrm{~m}$. m.), třikrát ve vyšši nadmořské výšce (3., 6. a 9. den pobytu), kontrolni desátý den po návratu do nižiny.

Pro rychlost běhu na úrovni aerobního $i$ anaerobního prahu stanoveného v nižině byly hodnoty SF $i$ koncentrace laktátu v průběhu všech testů ve výšce vždy vyšši (v porovnáni s nižinou). SF i koncentrace laktátu na úrovni kritické intenzity definované v nižině se při testech ve výšce nezměnila. Průměrné hodnoty SF i laktátu při kontrolním testu v nižině deset dnů po návratu z výšky byly pro všechny sledované intenzity zatížení nižši než hodnoty zjištěné v nižině před odjezdem do výšky.

Desetidenni pobyt a trénink ve výšce měl v námi testovaném modelu vliv na snižení sportovni výkonnosti běžců na lyžich v průběhu pobytu ve výšce a pozitivní efekt na rozvoj všech sledovaných intenzit zatižení po návratu do níziny.
\end{abstract}

\section{Abstract}

The article summarizes the results of the influence of 10 day stay and training in high altitude (1850 $\mathrm{m} \mathrm{ASL)}$ on sport performance changes of cross country skiers at the level of aerobic, anaerobic and critical intensity load measured by heart rate (HR) and lactate concentrations in capillary blood. For verification was used a non-standardized running field tests $(3 \times 2 \mathrm{~km}$, with 10 minute rest). 7 subjects (deliberate sample, cross country skiers) performed the test five times altogether: initially in lowlands (480 $\mathrm{m} \mathrm{ASL),} \mathrm{three} \mathrm{times} \mathrm{in} \mathrm{high} \mathrm{altitude}$ (3rd, 6th and 9th day of stay) and the last 10 days after return to lowlands.

$H R$ and lactate levels at aerobic and anaerobic thresholds were higher in high altitude compared to lowlands during all tests, however, they did not change at critical intensity in either the places. Average values of HR and lactate levels achieved during the lowland test 10 days after returning from high altitude were significantly lower at all three intensities in comparison with initial data.

The sport performance at aerobic and anaerobic thresholds during 10 day stay and training of cross country skiers in high altitude decreases, however significantly improves (in comparison with initial data) after the return to lowlands.

Klíčová slova: vyšši nadmořská výška, testováni, laktát, srdečni frekvence, sportovni trénink

Key words: high altitude, testing, lactate, heart rate, sport training

Za spolupráci děkujeme ing. Jiřimu Novotnému a Václavu Hamanovi. Výzkum byl podpořen z prostředkü: VZ MSM0021620864, PRVOUK P38, SVV 2014 - 260116 a VEGA 1/1175/12. 


\section{ÚVOD}

K problematice pobytu a tréninku ve vyšší nadmořské výšce (1 800 až $2400 \mathrm{~m} \mathrm{n}$. m.) byla publikována řada prací, které se shodují na významu zařazení výšky do př́ípravy (především) u vrcholových sportovců. Metaanalýza studií za posledních 30 let ukázala, že špičkoví sportovci při pobytu i tréninku v přírodní vyšší nadmořské výšce průměrně zlepší svou výkonnost přibližně o 5,2 \% v porovnání s přípravou v nížině (Bonetti \& Hopkins, 2009). Přes poměrnou četnost a obsažnost dnešních znalostí nejsou zdaleka všechny otázky tréninku za využití nižšího parciálního tlaku vzduchu vyřešeny.

Adaptace na vyšší nadmořskou výšku je relativně dlouhodobý komplexní proces. Dovalil et al. (1999), Fuchs \& Reiss (1990) i Wilber (2004) se shodují, že ideální pro úspěšnou adaptaci je přibližně 21 dnů pobytu a tréninku ve vyšší nadmořské výšce. Fuchs a Reiss (1990) uvádějí tři základní fáze tohoto procesu: akomodace (bezprostřední reakce na hypoxickou zátěž trvající 3 až 8 dnů), adaptace (charakterizovaná změnami organismu, trvá přibližně 8 dnů), aklimatizace (komplexní změny organismu, od přibližně šestnáctého dne pobytu). Úroveň trénovanosti a předchozí zkušenosti s výškou mohou pozitivně ovlivnit př́padné zkrácení procesu aklimatizace. Aktuálním trendem nejen v běžeckém lyžování, plynoucím ze socio-ekonomických důvodů, je zkracování pobytů ve výšce z historicky prověřených tř́ týdnů na deset až dvanáct dnů (Suchý \& Dovalil, 2009).

Přesná definice aktuální intenzity zatížení je důležitým vstupem pro řízení sportovního tréninku. Je známo, že v prvních dnech tréninku ve vyšší nadmořské výšce jsou hodnoty srdeční frekvence (SF) i koncentrace laktátu v kapilární krvi u neadaptovaných jedinců při stejné intenzitě zatížení jako v nížině významně vyšší. Při řízení tréninku je také nezbytné reflektovat (především v prvních deseti dnech pobytu ve výšce) neobvyklý průběh koncentrace laktátu v krvi. Před nástupem aklimatizačních procesů jsou hodnoty laktátu v krvi při stejné intenzitě zatížení vyšší než po nástupu aklimatizačních procesů. Tento jev je obvykle nazýván „laktátový paradox" (Hochachka et al., 2002; Lundby et al., 2000).

Převážná většina autorů ve shodě např́klad s Wilmorem et al. (2008) nebo Buncem (1990) pro potřeby sportovního tréninku zjednodušeně rozlišuje tři základní intenzity zatížení: aerobní (AP), anaerobní (ANP), kritická intenzita $(\mathrm{KI})$.

AP je plně energeticky kryta aerobní úhradou energie - tzn. za př́stupu kyslíku a využití glykogenu, později i tuků. Obvyklá hodnota laktátu na úrovni AP je 0,8 až 2 mmol.1 ${ }^{-1}$ v krvi (Keul et al., 1978).

ANP vyjadřuje nejvyšší intenzitu konstantního zatížení, při níž k úhradě energetických nároků nestačí aerobní procesy, výrazněji se uplatňují také procesy anaerobní, avšak celá látková výměna zůstává v dynamické rovnováze tvorby a utilizace laktátu (např. Keul et al., 1978). V tréninku má přesná definice aktuální individuální úrovně ANP zásadní význam, protože vyjadřuje okamžik nelineárního nárůstu kumulování laktátu v krvi v závislosti na intenzitě zatížení (např. Coen, 1997). Neumann et al. (1998) uvádějí obvyklou hodnotu ANP na hladině laktátu v krvi okolo 4 mmol. $1^{-1}$. U špičkově trénovaných vytrvalců se ANP může vyskytovat již v oblasti koncentrace laktátu v rozmezí 2 až 3 mmol. $1^{-1}$ (Janssen, 2001).

KI je obvykle definována jako maximální spotřeba kyslíku ve svalech. Další zvýšení intenzity nad úroveň KI již nevede k vyšší spotřebě kyslíku. Tato intenzita současně znamená značné zvýšení nároků na anaerobní procesy, které vedou k vysoké acidóze znemožňující delší dobu trvání zatížení (Hottenrott et al., 1994). Obvyklé hodnoty koncentrace laktátu pro KI jsou 5 až $7 \mathrm{mmol}^{-1}{ }^{-1}$, vždy v závislosti na somatotypu, poměru svalových vláken, sportovní specializaci a individuální trénovanosti v této intenzitě (Keul et al., 1978).

$\mathrm{S}$ ohledem na význam indikace změn akutní výkonnosti ve výšce v různých intenzitách zatížení před nástupem aklimatizačních procesů jsme se právě na tuto problematiku v rámci svého výzkumu zaměřili.

Testů a testových baterií určených k exaktnímu řízení sportovního tréninku i určování intenzity zatížení existuje celá řada. Neumann et al. (1998) rozdělují testy na laboratorní a terénní, principiálně je pak nutné rozlišovat standardizované a nestandardizované.

Výzkum byl dílčí součástí habilitační práce zaměřené na problematiku využití hypoxie a hyperoxie ve sportovním tréninku (Suchý, 2012).

\section{CÍL PRÁCE}

Cílem práce bylo posoudit efekt desetidenního pobytu a tréninku ve vyšší nadmořské výšce ( 1850 m n. m.) na aktuální změny (aerobní a anaerobní) výkonnosti u běžců na lyžích. Změny byly zjišt’ovány v jednotlivých fázích aklimatizačního procesu pro různé intenzity zatížení v nestandardizovaném terénním testu prostřednictvím hodnot SF a laktátu. 
Výsledky dosažené ve výšce byly srovnávány mezi sebou i s kontrolním testem v nížině, realizovaným bezprostředně před odjezdem do výšky. Pro ověření průběhu reaklimatizace bylo také zařazeno testování po návratu do nížiny.

\section{METODY}

Schéma 1: Prüběh terénního testu.

\begin{tabular}{|c|c|}
\hline minuty & aktivita \\
\hline-15 až $-0,5 \mathrm{~min}$ & rozevixeri \\
\hline $\begin{array}{r}-0,5 \mathrm{~min} \\
0 \mathrm{~min}\end{array}$ & $\begin{array}{l}\text { odbłr laktábu } \\
\text { start } 2 \mathrm{~km} \text { bXth na úrovri aerobnho prahu }\end{array}$ \\
\hline \multirow[t]{3}{*}{$8 \mathrm{až} 10 \mathrm{~min}$} & $\begin{array}{l}\text { Ukon'eri pruntho testu } \\
\text { (de indvidualhi výkornost) }\end{array}$ \\
\hline & $\begin{array}{l}\text { odber laktátu (trned po ukon'eri testu) } \\
\text { po celou dobu aktivri odpoťnek - chice }\end{array}$ \\
\hline & 2 min po ukončeri testu octär liktatau \\
\hline \multirow[t]{3}{*}{18 až $20 \mathrm{~min}$} & $\begin{array}{l}\text { (10 min po ukonǒeri pruniho testu) } \\
\text { start } 2 \mathrm{~km} \text { bĕh na úrovri anaerobriho prahu }\end{array}$ \\
\hline & $\begin{array}{l}\text { odbĕr laktátu (Inned po ukončeri testu) } \\
\text { po celou dobu aktivíi odpočnek - chüze }\end{array}$ \\
\hline & 2 min po ukončeri testu odbĕr laktátu \\
\hline 35 až $43 \mathrm{~min}$ & $\begin{array}{l}\text { (10 min po ukončeni druhtho testu) } \\
\text { start } 2 \mathrm{~km} \text { b̧̌h na úrovri kribcké intenzity }\end{array}$ \\
\hline & 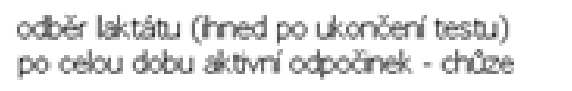 \\
\hline & 2 min po ukončeri testu odbër laktátu \\
\hline $50 \mathrm{až} 70 \mathrm{~min}$ & 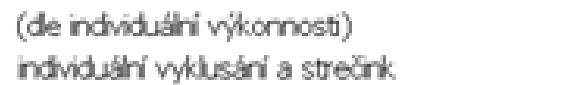 \\
\hline
\end{tabular}

Pro ověření stanovených cílů jsme využili nestandardizovaný terénní běžecký test, který zahrnoval třikrát dva kilometry běhu na úrovni aerobního prahu, anaerobního prahu a kritické intenzity. Interval aktivního odpočinku mezi jednotlivými úseky byl 10 minut. Jedná se v podstatě o modifikovanou verzi testu, kterou historicky jako jedni z prvních koncem šedesátých let publikovali Buskirk et al. (1967) a Faulkner et al. (1968).

Rychlost běhu pro jednotlivé úseky (aerobní, anaerobní a kritická intenzita) byla pro každého účastníka stanovena individuálně na základě stupňovaného zátěžového testu (Bunc, 1990), který absolvoval před zahájením pokusu v nížině. Při všech testech i intenzitách zatížení museli sledovaní běžci na lyžích dodržovat rychlost běhu definovanou na základě zátěžových testů v nížině, ač se aktuální intenzita zatížení př́i dané rychlosti běhu změnila.

Všechny testy se uskutečnily na 500m úseku asfaltové cesty s rovinatým profilem (převýšení cca $4 \mathrm{~m}$ ), které bylo v Jilemnici i Livignu totožné. Na 100 m, 200 m a 500 m byli členové realizačního týmu, kteří kontrolovali, zda se aktuální dosahované mezičasy sledovaných běžců na lyžích shodují s plánovanými. Pokud se proband od individuálního plánovaného času odchýlil, tak byl ihned informován, zda má zrychlit nebo zpomalit.

Aktuální koncentrace laktátu byla zjištována z kapilární krve z prstu před zahájením testu, po ukončení každého úseku a následně ve třetí a páté minutě po ukončení testu (pro posouzení kinetiky uklidnění). Vzorky 
krve byly analyzovány přístrojem SenzoStar GL (www.diasys-diagnostics.com), který dle tvrzení výrobce měří $\mathrm{s}$ variačním koeficientem $<2,5 \%$ při 24 vzorcích.

Po celou dobu trvání testu byly prostřednictvím sporttesterů firmy Polar (www.polar.fi) kontinuálně sledovány hodnoty SF. Údaje uložené v hodinkách byly následně vyhodnoceny za využití software Polar precision performance stejné firmy. Podrobný průběh testování uvádí schéma č. 1 .

Testy se konaly v těchto konkrétních termínech:

- T1: 10. 9. 2010 - bezprostředně před odjezdem do výšky (Jilemnice, $485 \mathrm{~m} \mathrm{n.} \mathrm{m.),}$

- T2: 13. 9. 2010 - 3. den po př́jezdu do výšky (Livigno, 1835 m n. m.),

- T3: 16. 9. 2010 - 6. den po př́jezdu (Livigno, $1835 \mathrm{~m} \mathrm{n.} \mathrm{m.),}$

- T4: 19.9. 2010 - 9. den po př́ijezdu (Livigno, $1835 \mathrm{~m} \mathrm{n.} \mathrm{m.),}$

- T5: 1. 10. 2010 - deset dnů po návratu z výšky (Jilemnice, 485 m n. m.).

Byly tedy provedeny na počátku a uprostřed fáze akomodace a na počátku fáze adaptace. Termín druhého a čtvrtého testu rámcově odpovídal kritickým obdobím pobytu ve výšce (Dovalil et al., 1999). Realizace testu deset dnů po návratu přibližně odpovídá ukončení druhé fáze reaklimatizace (Wilber, 2004).

Jednalo se o př́padovou studii, protože s ohledem na technicko-organizační aspekty byl výzkum realizován u sedmi (z toho 3 muži) běžců na lyžích, jejichž podrobnou charakteristiku uvádí tabulka č. 1. Všichni zúčastnění byli členy Sportovního centra mládeže a studenty Sportovního gymnázia Jilemnice. Pravidelně se účastní závodů Českého poháru v běhu na lyžích. Někteří ze sledovaných byli zařazeni do reprezentačních výběrů. S ohledem na skutečnost, že se v době testování nacházeli v přípravném období, absolvovali tréninkové zatížení v rozsahu 15 až 20 hodin za týdenní mikrocyklus jak v období před vstupní diagnostikou, tak během samotného výzkumu. Tréninkový program byl v průběhu jednotlivých mikrocyklů po dobu testování v podstatě totožný, $\mathrm{s}$ výjimkou úprav souvisejících s cestováním do Livigna a zpět.

Tab. 1: Charakteristika probandi̊ - běžců na lyžich $(n=7)$.

\begin{tabular}{|l|c|c|c|c|c|c|c|}
\hline $\begin{array}{l}\text { zjišt'ovaný } \\
\text { parametr }\end{array}$ & $\begin{array}{c}\text { věk } \\
{[\mathrm{roky}]}\end{array}$ & $\begin{array}{c}\text { hmotnost } \\
{[\mathrm{kg}]}\end{array}$ & $\begin{array}{c}\text { výška } \\
{[\mathrm{cm}]}\end{array}$ & $\begin{array}{c}\text { vit. kap. } \\
\text { plic [l] }\end{array}$ & $\begin{array}{c}\text { aktivní sport } \\
{[\text { roky] }}\end{array}$ & $\begin{array}{c}\text { FEV } \\
{[1]}\end{array}$ & $\begin{array}{c}\text { FEV1 } \\
{[\%]}\end{array}$ \\
\hline průměr/ & 18,8 & 68,3 & 176,8 & 4,7 & 5,9 & 4,3 & 94 \\
směr. odchylka & $\pm 3,4$ & $\pm 7,1$ & $\pm 4,1$ & $\pm 0,6$ & $\pm 4,5$ & $\pm 0,8$ & \pm 6 \\
\hline
\end{tabular}

Shoda nebo statistická významnost rozdílu středních hodnot sledovaných veličin byla zjišt’ována parametrickým párovým t-testem pro dva závislé výběry. S ohledem na charakter výzkumu jsme se rozhodli, v souladu s obdobnými výzkumy (např. Bonetti a Hopkins, 2009), posuzovat statistickou významnost rozdílů na hladině významnosti $\mathrm{p}<0,05$.

Design výzkumu je v souladu s Helsinskou deklarací a byl schválen Etickou komisí UK FTVS dne 23. srpna 2009. Všichni zúčastnění signovali před testováním informovaný souhlas. Autor v souvislosti s tímto výzkumem nemá žádný konflikt zájmů.

\section{VÝSLEDKY}

Šetření proběhlo v souladu se stanovenou metodikou.

Pro intenzity běhu na úrovni AP a ANP (zjištěné v nížině) byly průměrné hodnoty SF v průběhu všech testů (viz tabulky 2 a 3 ) ve výšce vždy statisticky významně vyšší v porovnání s nížinou $(p<0,05)$. Statistické významnosti nedosáhly pouze rozdíly SF v T3.

SF se při rychlosti běhu na úrovni KI (v nížině) při testech ve výšce statisticky významně nezměnila. Důvodem je skutečnost, že při této intenzitě zatížení nelze očekávat ve výšce další změnu SF.

Kinetika uklidnění sledovaná ve třetí minutě po poslední části testu, která byla absolvována na úrovni KI, kopíruje rozdílné hodnoty dosažené v tomto závěrečném testu. Průměrná SF ve třetí minutě po ukončení testů v nížině po návratu z výšky byla statisticky významně vyšší o 6 tepů.min ${ }^{-1}$ než u testu před odjezdem do výšky. Toto zjištění bohužel nejsme schopni přesně interpretovat, důvodem může být například předcházející větší objem a intenzita tréninku ve srovnání se zatížením před úvodním kontrolním testem v nížině. 
Tab. 2: Popisné statistiky hodnot SF při rychlosti běhu (určené v nižině) u sledovaných běžců na lyžich $(n=7)$ při všech testech ${ }^{I}$.

\begin{tabular}{|c|c|c|c|c|c|c|c|c|c|c|}
\hline \multirow{2}{*}{$\begin{array}{l}\text { hodnota } \\
\left.\text { [tepů.min }{ }^{-1}\right] / \text { testování }\end{array}$} & \multicolumn{5}{|c|}{$\begin{array}{c}\text { aerobní intenzita } \\
\text { (rychlost běhu dle nížiny) }\end{array}$} & \multicolumn{5}{|c|}{$\begin{array}{c}\text { anaerobní intenzita } \\
\text { (rychlost běhu dle nížiny) }\end{array}$} \\
\hline & $\mathrm{T} 1$ & $\mathrm{~T} 2$ & T3 & $\mathrm{T} 4$ & T5 & $\mathrm{T} 1$ & $\mathrm{~T} 2$ & T3 & $\mathrm{T} 4$ & T5 \\
\hline průměr & 155,1 & 161,3 & 156,9 & 163,4 & 151 & 177,3 & 181,0 & 176,6 & 181,4 & 171 \\
\hline směr. odchylka & 9,00 & 7,48 & 7,85 & $\mathbf{8 , 5 8}$ & 7,68 & 9,63 & 7,54 & 8,21 & 9,47 & 6,95 \\
\hline prům. odchylka & 8,45 & 5,76 & 7,59 & 7,22 & 6,73 & 8,82 & 6,86 & 7,35 & 8,65 & 6,57 \\
\hline hodnota & \multicolumn{5}{|c|}{$\begin{array}{l}\text { kritická intenzita } \\
\text { chlost běhu dle nížiny) }\end{array}$} & \multicolumn{5}{|c|}{3 min. po ukončení testu } \\
\hline $\begin{array}{l}\left.\text { [tepů.min }{ }^{-1}\right] / \\
\text { testování }\end{array}$ & $\mathrm{T} 1$ & $\mathrm{~T} 2$ & $\mathrm{~T} 3$ & $\mathrm{~T} 4$ & $\mathrm{~T} 5$ & $\mathrm{~T} 1$ & $\mathrm{~T} 2$ & $\mathrm{~T} 3$ & $\mathrm{~T} 4$ & T5 \\
\hline průměr & 187 & 187 & 183 & 186 & 182 & 120 & 124 & 118 & 122 & 109 \\
\hline směr. odchylka & 9,71 & 7,89 & 7,34 & $\mathbf{9 , 5 9}$ & 9,11 & 14,83 & 11,30 & 14,42 & 16,17 & 13,61 \\
\hline prům. odchylka & 8,20 & 6,86 & 6,33 & 8,61 & 7,55 & 12,22 & $\mathbf{9 , 5 1}$ & 12,16 & 11,43 & 9,63 \\
\hline
\end{tabular}

Tab. 3: Popisné statistiky hodnot SF při rychlosti běhu (určené v nižině) u sledovaných běžců na lyžich $(n=7)$ při v̌̌ech testech ${ }^{I}$.

\begin{tabular}{|c|c|c|c|c|c|c|c|c|c|c|c|c|}
\hline \multicolumn{5}{|c|}{ aerobní intenzita } & \multicolumn{4}{|c|}{ anaerobní intenzita } & \multicolumn{4}{|c|}{ kritická intenzita } \\
\hline \multicolumn{5}{|c|}{ (rychlost běhu dle nížiny) } & \multicolumn{4}{|c|}{ (rychlost běhu dle nížiny) } & \multicolumn{4}{|c|}{ (rychlost dle nížiny) } \\
\hline & $\mathrm{T} 2$ & $\mathrm{~T} 3$ & $\mathrm{~T} 4$ & T5 & $\mathrm{T} 2$ & $\mathrm{~T} 3$ & $\mathrm{~T} 4$ & T5 & $\mathrm{T} 2$ & $\mathrm{~T} 3$ & $\mathrm{~T} 4$ & T5 \\
\hline $\mathrm{T} 1$ & $\mathbf{0 , 0 3 6}$ & 0,158 & 0,021 & $\mathbf{0 , 0 2 4}$ & 0,045 & 0,335 & $\mathbf{0 , 0 2 9}$ & 0,054 & 0,429 & 0,079 & 0,436 & 0,000 \\
\hline $\mathrm{T} 2$ & & 0,074 & 0,250 & $\mathbf{0 , 0 1 0}$ & & $\mathbf{0 , 0 0 1}$ & 0,383 & $\mathbf{0 , 0 0 7}$ & & 0,002 & 0,244 & $\mathbf{0 , 0 3 8}$ \\
\hline T3 & & & 0,007 & $\mathbf{0 , 0 0 2}$ & & & $\mathbf{0 , 0 0 7}$ & 0,053 & & & 0,019 & 0,282 \\
\hline $\mathrm{T} 4$ & & & & 0,003 & & & & 0,013 & & & & 0,029 \\
\hline \multicolumn{5}{|c|}{3 min. po ukončení testu } & & & & & & & & \\
\hline & $\mathbf{T 2}$ & T3 & $\mathbf{T 4}$ & T5 & & & & & & & & \\
\hline $\mathrm{T} 1$ & 0,209 & 0,067 & 0,381 & $\mathbf{0 , 0 0 0}$ & & & & & & & & \\
\hline $\mathrm{T} 2$ & & $\mathbf{0 , 0 2 3}$ & 0,333 & $\mathbf{0 , 0 0 1}$ & & & & & & & & \\
\hline $\mathrm{T} 3$ & & & 0,186 & $\mathbf{0 , 0 2 2}$ & & & & & & & & \\
\hline $\mathrm{T} 4$ & & & & 0,044 & & & & & & & & \\
\hline
\end{tabular}

S ohledem na průběh testu nehodnotíme hladinu laktátu po rozcvičení, protože nemá dostatečnou vypovídací hodnotu, přestože jsme se snažili o standardní řízení průběhu rozcvičení. Úvodní hodnoty byly odebírány pouze pro kontrolu, zda některý ze sledovaných běžců na lyžích nemá př́liš vysokou klidovou koncentraci laktátu naznačující možné přetížení, a tedy také neschopnost úspěšně absolvovat zatížení kladené na něj v průběhu testování.

Průměr koncentrace laktátu na úrovni AP byl statisticky významně o 0,4 a 0,54 mmol. ${ }^{-1}$ vyšší při T1 a T5 měření v porovnání s nížinou. Průměrné hodnoty měření u T3 byly v podstatě totožné jako v nížině.

Zjištěné průměrné hodnoty koncentrace laktátu pro oblast ANP (indikovaného v nížině) ukazují, že deset dnů tréninku a pobytu ve výšce mělo u sledovaných běžců na lyžích po celou dobu statisticky významný vliv na jejich zvýšení. Hodnoty laktátu při všech třech měřeních ve výšce byly o 1 až 1,5 mmol.1 ${ }^{-1}$ vyšší než při obou kontrolních měřeních v nížině (viz tab. 4 a 5).

Laktát byl po ukončení posledního úseku na individuální úrovni KI byl při všech odběrech ve výšce průměrně vyšší, ale pouze u měření T2 statisticky významně.

Kontrolní měření deset dnů po návratu z výšky (T5) prokázalo u všech sledovaných intenzit statisticky významně nižší hodnoty koncentrace laktátu v rozmezí 1 až 2,5 mmol.1 $1^{-1}$ než u všech měření ve výšce.

${ }^{1}$ Jedná se o průměrné hodnoty SF měrené vždy při druhém kilometru př́slušného úseku. Pro třetí minutu uklidnění byl měren prưměr za 30 s (2:45 - 3:15). 
Průběh uklidnění ve třetí a páté minutě po ukončení úseku KI kopíruje rozdílné hodnoty dosažené v tomto závěrečném testu. Průměrná koncentrace laktátu v rámci uklidnění byla ve výšce vždy o 0,5 až 2,5 mmol..$^{-1}$ vyšší než hodnoty po ukončení obou testů v nížině. Rozdíly byly statisticky významné, s výjimkou srovnání nížiny před odjezdem a třetí minuty uklidnění po druhém testu ve výšce (T3).

Tab. 4: Koncentrace laktátu [mmol..$\left.^{-1}\right]$ u sledovaných běžcu na lyžich $(n=7)$ při všech testech.

\begin{tabular}{|c|c|c|c|c|c|c|c|c|c|c|}
\hline \multirow{2}{*}{$\begin{array}{l}\text { hodnota } \\
{\left[\text { mmol.1 } 1^{-1}\right] /} \\
\text { testování }\end{array}$} & \multicolumn{5}{|c|}{ hodnoty po rozcvičení } & \multicolumn{5}{|c|}{$\begin{array}{c}\text { aerobní intenzita } \\
\text { (rychlost běhu dle nížiny) }\end{array}$} \\
\hline & T1 & $\mathbf{T 2}$ & $\mathbf{T 3}$ & T4 & T5 & T1 & $\mathbf{T} 2$ & T3 & T4 & T5 \\
\hline průměr & 0,97 & 0,88 & 1,20 & 1,24 & 1,19 & 1,16 & 1,56 & 1,09 & 1,70 & 0,94 \\
\hline směr. odchylka & 0,26 & 0,20 & 0,29 & 0,28 & 0,34 & 0,31 & 0,63 & 0,25 & 0,32 & 0,20 \\
\hline prům. odchylka & 0,18 & 0,16 & 0,22 & 0,21 & 0,31 & 0,27 & 0,58 & 0,22 & 0,22 & 0,17 \\
\hline \multirow{2}{*}{$\begin{array}{l}\text { hodnota } \\
{\left[\text { mmol.1 } 1^{-1}\right] /} \\
\text { testování }\end{array}$} & \multicolumn{5}{|c|}{ anaerobní intenzita } & \multicolumn{5}{|c|}{ kritická intenzita } \\
\hline & $\mathrm{T} 1$ & $\mathrm{~T} 2$ & $\mathrm{~T} 3$ & $\mathrm{~T} 4$ & $\mathrm{~T} 5$ & $\mathrm{~T} 1$ & $\mathrm{~T} 2$ & $\mathrm{~T} 3$ & $\mathrm{~T} 4$ & $\mathrm{~T} 5$ \\
\hline průměr & 3,52 & 5,21 & 4,68 & 5,08 & 3,39 & 6,65 & 8,45 & 6,75 & 7,80 & 5,99 \\
\hline směr. odchylka & 0,69 & 1,31 & 0,82 & $1,0 J$ & 1,09 & 1,70 & 0,99 & 1,15 & 1,43 & 1,53 \\
\hline prům. odchylka & 0,58 & 0,95 & 0,70 & 0,98 & 0,97 & 1,41 & 0,92 & 1,12 & 1,22 & 1,23 \\
\hline \multirow{2}{*}{$\begin{array}{l}\text { hodnota } \\
{\left[\text { mmol.1 } 1^{-1}\right] /} \\
\text { testování }\end{array}$} & \multicolumn{5}{|c|}{ uklidnění 3 min. po ukončení testu } & \multicolumn{5}{|c|}{ uklidnění 5 min. po ukončení testu } \\
\hline & $\mathrm{T} 1$ & $\mathrm{~T} 2$ & $\mathrm{~T} 3$ & $\mathrm{~T} 4$ & $\mathrm{~T} 5$ & $\mathrm{~T} 1$ & $\mathrm{~T} 2$ & $\mathrm{~T} 3$ & $\mathrm{~T} 4$ & T5 \\
\hline průměr & 4,76 & 7,22 & 5,71 & 7,02 & 4,77 & 3,84 & 6,88 & 5,31 & 4,29 & 4,11 \\
\hline směr. odchylka & 2,53 & 1,27 & 1,04 & 1,58 & 1,43 & 2,06 & 1,34 & 0,85 & 1,02 & 1,39 \\
\hline prům. odchylka & 1,96 & 1,05 & 0,85 & 1,23 & 1,06 & 1,52 & 0,98 & 0,72 & 0,83 & 1,01 \\
\hline
\end{tabular}

Tab. 5: Statistická významnost rozdili̊ koncentrace laktátu [mmol.l-1]v průběhu jednotlivých testů mezi jednotlivými dny; P: hodnota párového t-testu (statisticky významné rozdíly jsou uvedeny tučně).

\begin{tabular}{|c|c|c|c|c|c|c|c|c|c|c|c|c|}
\hline \multirow{2}{*}{\multicolumn{5}{|c|}{ hodnoty po rozcvičení }} & \multicolumn{4}{|c|}{ aerobní intenzita } & \multicolumn{4}{|c|}{ anaerobní intenzita } \\
\hline & & & & & \multicolumn{4}{|c|}{ (rychlost běhu dle nížiny) } & & & & \\
\hline & $\mathrm{T} 2$ & T3 & $\mathrm{T} 4$ & T5 & $\mathrm{T} 2$ & T3 & $\mathrm{T} 4$ & T5 & $\mathrm{T} 2$ & $\mathrm{~T} 3$ & $\mathrm{~T} 4$ & T5 \\
\hline $\mathrm{T} 1$ & 0,286 & 0,031 & 0,090 & 0,045 & $\mathbf{0 , 0 2 1}$ & 0,173 & 0,003 & 0,015 & $\mathbf{0 , 0 1 5}$ & 0,005 & 0,001 & $\mathbf{0 , 0 2 2}$ \\
\hline $\mathrm{T} 2$ & & 0,024 & 0,012 & 0,045 & & $\mathbf{0 , 0 3 4}$ & 0,297 & 0,015 & & 0,113 & 0,393 & 0,022 \\
\hline $\mathrm{T} 3$ & & & 0,403 & 0,470 & & & 0,002 & $\mathbf{0 , 0 1 0}$ & & & 0,094 & 0,013 \\
\hline $\mathrm{T} 4$ & & & & 0,392 & & & & 0,001 & & & & 0,001 \\
\hline \multicolumn{5}{|c|}{ kritická intenzita } & \multicolumn{4}{|c|}{$\begin{array}{c}\text { uklidnění } \\
3 \text { min. po ukončení testu }\end{array}$} & \multicolumn{4}{|c|}{$\begin{array}{l}\text { uklidnění } \\
5 \text { min. po ukončení testu }\end{array}$} \\
\hline & $\mathrm{T} 2$ & $\mathrm{~T} 3$ & $\mathrm{~T} 4$ & T5 & $\mathrm{T} 2$ & T3 & $\mathrm{T} 4$ & T5 & $\mathrm{T} 2$ & T3 & $\mathrm{T} 4$ & T5 \\
\hline $\mathrm{T} 1$ & 0,036 & 0,417 & 0,095 & $\mathbf{0 , 0 0 7}$ & $\mathbf{0 , 0 3 5}$ & 0,161 & $\mathbf{0 , 0 2 7}$ & $\mathbf{0 , 0 1 7}$ & $\mathbf{0 , 0 1 1}$ & 0,047 & 0,009 & $\mathbf{0 , 0 0 8}$ \\
\hline $\mathrm{T} 2$ & & $\mathbf{0 , 0 0 7}$ & 0,156 & $\mathbf{0 , 0 0 7}$ & & 0,008 & 0,389 & $\mathbf{0 , 0 1 7}$ & & 0,009 & 0,133 & $\mathbf{0 , 0 0 8}$ \\
\hline $\mathrm{T} 3$ & & & $\mathbf{0 , 0 3 0}$ & $\mathbf{0 , 0 3 4}$ & & & 0,004 & 0,061 & & & 0,002 & $\mathbf{0 , 0 2 5}$ \\
\hline $\mathrm{T} 4$ & & & & 0,016 & & & & $\mathbf{0 , 0 0 8}$ & & & & $\mathbf{0 , 0 0 4}$ \\
\hline
\end{tabular}

U všech tří sledovaných intenzit zatížení se ukázalo, že v testu T3 měli probandi o 6 až 8 tepů.minn ${ }^{-1}$ nižší průměrnou SF než při úvodním a závěrečném testování ve výšce a také vyšší než u obou testů v nížině. Změny koncentrace laktátu měly stejnou tendenci a vykazovaly o 0,5 až 2,5 mmol. $1^{-1}$ nižší hodnoty u T3. Uváděné rozdíly nebyly vždy statisticky významné. 


\section{DISKUSE}

Pozitivní efekt vyšší nadmořské výšky na zvýšení aktuální úrovně trénovanosti v oblasti zatížení na úrovni AP a ANP po návratu do nížiny, který prokázala naše měření, koresponduje např́iklad s výzkumy Hochachky et al. (2002). Získaná data také potvrzují poznatky publikované již v sedmdesátých letech (např. Wasserman et al. 1973), že KI není v průběhu prvních deseti dnů pobytu ve výšce vhodné rozvíjet.

Průměrné údaje o koncentraci laktátu a intenzitě SF ukazují shodu na nižších hodnotách u testu šestý den po př́ijezdu do výšky (T3) při srovnání s prvním (T2) a posledním testem (T4) ve výšce. Ne všechny rozdíly jsou statisticky významné. Tuto informaci je poměrně komplikované interpretovat, ale domníváme se, že zjištěný pokles odpovídá publikovaným informacím (napřs. Dovalil et al., 1999; Wilber, 2004) popisujícím průběh aklimatizačních procesů a krizových dnů. Laktátový paradox (Hochachka et al., 2002; Lundby et al., 2000) jsme v rámci našeho výzkumu potvrdili pouze měřením T3 (šestý den pobytu ve výšce).

Zásadní pro posouzení vlivu desetidenního pobytu ve výšce na následnou výkonnost v nížině je srovnání koncentrací laktátu a hodnot SF u obou testování v nížině - tj. bezprostředně před odjezdem do výšky (T1) a deset dnů po návratu ze soustředění (T5). Průměrná koncentrace laktátu v krvi při stejné rychlosti běhu byla u všech sledovaných intenzit statisticky významně nižší po návratu ze soustředění ve srovnání s hodnotami před odjezdem. Největší průměrný pokles $\left(0,66\right.$ mmol.1-1 ${ }^{-1}$ tj. $\left.9,3 \%\right)$ byl zaznamenán u kritické intenzity. Průměrné hodnoty SF byly v testu po návratu (T5) nižší o 4 až 6 tepů.min-1 (tj. 4 až 17 \%) než před odjezdem do výšky (T1).

Většina autorů pracuje pro potřeby verifikace intenzity se SF, možná proto se nám nepodařilo dohledat ekvivalentní studie pro srovnání hodnot laktátu. Zjištěné rozdíly podle našeho názoru naznačují, že pro přesnější ř́zení tréninku je vhodnější souběžně se SF zjištovat také koncentraci laktátu v krvi. Ke sledování změn pro oblast kritické (závodní) intenzity ve výšce nebylo v posledních letech publikováno mnoho studií. Podle Wilbera (2004) je důvodem skutečnost, že v posledních letech řada špičkových sportovců využivá v průběhu ročního tréninkového cyklu výšku s úspěchem pravidelně (někteří zde žijí trvale). Z těchto důvodů nemají trenéři i fyziologové důvody prověřené přístupy znovu ověřovat.

Průběh regenerace po ukončení nestandardizovaného testu zjišt’ovaný prostřednictvím odběru laktátu ve třetí a páté minutě probíhal jen po úseku absolvovaném KI. Zpětně se domníváme, že by bylo možné získat vypovídající data $\mathrm{k}$ průběhu regeneračních procesů také $\mathrm{z}$ hodnot laktátu $\mathrm{v}$ krvi ve třetí a páté minutě po dokončení úseku na úrovni AP a ANP.

Příspěvek přináší výsledky, které při správné interpretaci mohou přispět ke zvýšení efektivnosti tréninkového procesu mladých lyžařů běžců. Je vhodné, aby se trenéři více zamýšleli nad zatížením ve vyšší nadmořské výšce, dále je třeba posoudit efektivitu jednoho desetidenního či opakovaného pobytu v určitých časových intervalech.

Při koncipování designu výzkumu bylo zvažováno také využití specifičtějšího testu na kolečkových lyžích, ale $\mathrm{z}$ bezpečnostních i technicko-organizačních důvodů byl nakonec vybrán běh. Rovněž byla zvažována prezentace individuálních hodnot, prípadně rozdělení probandů na muže a ženy, ale vzhledem k počtu probandů a rozsahu článku nebylo toto členění realizováno.

\section{ZÁVĚR}

Zjištěné výsledky prokazují, že desetidenní pobyt a trénink ve vyšší nadmořské výšce měl u sledovaných běžců na lyžích z hlediska SF i koncentrace laktátu v krvi pozitivní vliv na následnou lepší aerobní a anaerobní výkonnost v nížině. Pobyt a trénink ve vyšší nadmořské výšce má vliv na akutní zhoršení sportovní výkonnosti posuzované prostřednictvím SF a laktátu.

Výsledky mají omezenou platnost pro námi stanovené modelové zatížení u běžců na lyžích verifikované koncentrací laktátu a hodnot SF.

\section{LITERATURA}

Bonetti, D.L. \& Hopkins, W.G. (2009). Meta-analysis of sea level performance following adaptation to hypoxia. Sports medicine 39, 107-127.

Bunc, V. (1990). Biokybernetický př́stup k hodnocení reakce organismu na tělesné zatižení. Praha: Univerzita Karlova.

Buskirk, E.R. et al. (1967). Maximal performance at altitude and on return from altitude in conditioned runners. 
Journal of Applied Physiology 23, 259-266.

Coen, B. (1997). Individuelle anaerobe Schwelle. Köln: Sport und Buch Strauss.

Dovalil, J. et al. (1999). Sportovní výkon a trénink ve vyšši nadmořské výšce. Praha: ČOV.

Faulkner, B. et al. (1968). Maximum aerobic capacity and running performance at altitude. Journal of Applied Physiology 24, 685-691.

Fuchs, U., \& Reiss, M. (1990). Höhentraining: das erfolgs konzept der ausdauer sportarten (Trainerbibliothek 27). Münster: Philippkaverlag.

Hochachka, P.W. et al. (2002). The lactate paradox in human high-altitude physiological performance. News in physiological Sciences 17, 122-126.

Hottenrott, K. (1994). Ausdauer training. Lüneberg: Wehdmeier und Pulschverlag. Janssen, J.G.J.M. (2001). Lactate threshold training. Champagne: Human Kinetics.

Keul, J. et al. (1978). Die aerobe und anaerobe Kapazität grundlage für die leistungs Diagnostik. Leistungssport 1, 22-32.

Lundby, C., Saltin, B. \& Van Hall, G. (2000). The „lactate paradox“ evidence for a change in the course of acclimatization to severe hypoxia in lowlanders, Acta Physiologica Scandinavica 179, 265-269.

Neumann, G., Pfützner, A. \& Berbalk, S. (1998). Optimiertes ausdauer training. Aachen: Meyer \& Meyer Verlag.

Suchý, J. (2012). Využití hypoxie a hyperoxie ve sportovním tréninku. Praha: Karolinum.

Suchý, J. \& Dovalil, J. (2009) Problematika tréninku ve vyšší nadmořské výšce z pohledu trenérů. Phys. Educ. Sport 18 (3-4), 4-8.

Wasserman, K. et al. (1973). Anaerobic treshold and respiratory gas exchange during exercise. Journal of Applied Physiology 2, 236-243.

Wilber, R.L. (2004). Altitude training and athletic perfomance. Champaign: Human Kinetics.

Wilmore, J., Costill, D. \& Kenney, W. (2008). Physiology of sport and exercise. Champaign: Human Kinetics. www.diasys-diagnostics.com [on line, 20. ř́ína 2013]

www.polar.fi [on line, 20. června 2013] 